\title{
Comparative Room Burn Study of Furnished Rooms from the United Kingdom, France and the United States
}

\author{
Matthew S. Blais* (1), Karen Carpenter and Kyle Fernandez, Fire Technology \\ Department, Southwest Research Institute, 6220 Culebra Rd, San Antonio, \\ $T X 78238$, USA
}

Received: 6 March 2019/Accepted: 5 July 2019

\begin{abstract}
The wide variety in country specific fire codes can dramatically affect the fire safety of home furnishings resulting in more or less escape time from structure fires. This study uses three replicates of identical rooms for each of the countries tested (France, United Kingdom, US) to increase reliability of data for a more reliable comparison. France and the US rely on smolder only furniture flammability standards while the United Kingdom relies on a combination of smolder and open flame ignition test. Each test room contained a 3 cushion couch, chair and flat panel television of identical models/manufacturers purchased from the respective countries. Additionally, each room was fitted with an identical coffee table, end table, curtain, and bookcase obtained from Walmart in the United States and $12 \mathrm{~kg}$ of books. All rooms were meticulously set-up to ensure comparability of results. Flat panel televisions were purchased from electronic stores in the three countries, all were $1.4 \mathrm{~m} \mathrm{(55}$ inch) Samsung FPD LED models of as similar design as possible in the markets purchased. The couches and chairs were the same Ektorp furniture line of identical color purchased from Ikea. All FPD TVs and furniture appeared to be identical. All room burns were conducted in a standard ISO 9705 room. Heat release was measured by oxygen consumption calorimetry and smoke development by light dispersion in the ventilation duct. Acute toxicity measurements were made using FTIR at two collection points, the door way and at crawling height in the center of the room. Other smoke constituents were measured for concentration of PAH, VOC, SVOCs and chlorinated and brominated dioxins and furans. Two separate collection events were performed, before and after white smoke transitioned to black smoke. The time to transition from white to black smoke for the British furnishings was five times as long as that observed for the French and US models. The same is true of the time to flashover. The average pHHR for the British rooms was $200 \mathrm{KW}$ less than the US and $400 \mathrm{KW}$ less than the French rooms. All rooms had pHHR between 2.5 MW and 3.3 MW. Total smoke produced for the British rooms was half that of the French and US and the Peak Smoke was delayed for the British rooms by approximately $12 \mathrm{~min}$. This study illustrated that the UK standard does provide a significantly better performance for an identical size and shaped couch based on time to pHHR, pHHR, time to peak smoke, and total smoke. In addition, the chemical composition of the smoke generated in the room burns featuring UK furniture were less
\end{abstract}

\footnotetext{
* Correspondence should be addressed to: Matthew S. Blais, E-mail: mblais@swri.org
} 
acutely toxic based on $\mathrm{HCN}$ and $\mathrm{CO}$ emission. The time to toxic levels for these gases was delayed $15 \mathrm{~min}$. The French and US rooms reached 1200 and $1600 \mathrm{ppm}$ for $\mathrm{HCN}$ at the doorway in $6 \mathrm{~min}$. The chronic toxicity of the UK rooms also appears to be less based on the lower molecular weight and lower concentration of PAH produced. These results directly contradict results published by Stec and Hull. The condition of the test do affect the results. It is critical to test under realistic conditions to be able to predict the performance of materials in home fires.

Keywords: Furnishing fire testing, Couches, Flat panel televisions, Chairs, Acute toxicity, Heat release, Smoke measurement, Fully furnished room burns

\section{Introduction}

Controversy surrounds fire codes associated with home furnishings and electronics. Significant fire risk is associated with large flat panel televisions (FPT) and well-padded furniture; couches, loveseats and chairs [1,2]. Fires where the furnishings in living rooms are the first item ignited are a leading cause of fire deaths [3]. Fire safety codes for furnishings and electronics vary widely from country to country. How do we make items safe from fire loss while at the same time addressing concerns of potential health risks associated with the inclusion of fire retardants [4]?

Examples of varied fire codes can be highlighted by the comparison of furniture standards in United Kingdom [5], France [6] and the United states [7]. The British have what is probably the most demanding fire standard for furniture in the world. BS 5852 uses a series of seven different ignition sources ranging in size from a smoldering cigarette to a large crib equaling a $2 \mathrm{~kW}$ open flame ignition source [8]. The United States does not have a national code but does have state driven codes that are in the process of changing. California drives the furniture standards in the United States as the largest market in the US. Cal TB 117 regulates the furniture fire performance for home furnishings. The changes to this standard in 2013 eliminated the open flame ignition test and rely on smoldering ignition sources to demonstrate fire safety. In France furniture must comply with FR EN 1021-1 [6] which is also a smolder only standard.

Another area of concern is the acute and chronic toxicity of smoke generated in fires. Numerous claims suggest that fire retardants increase the toxicity of smoke by generating high levels of acid gases and that the products of incomplete combustion (PICs) are increased [9-11]. Other fire scientists have published rebuttals to this concept $[12,13]$.

Due to the variable standards of fire resistance for furniture across countries, a study looking at multiple replicates of identical furniture from 3 different countries was conducted. The purpose being to determine if differences in fire standards resulted in different performance in fire under realistic conditions. Testing was performed in a standard room in general accordance with ISO 9705 [14] using 3 progressively larger ignition sources as described in British standard BS 5852 . The open flame ignition sources crib 4, 5, and 6 [8] were chosen to bracket the BS 5852 passing standard of no progressive burning when subjected to crib 5. 
Smoke generation from fires varies extensively from one phase of fire to another [15]. In early stages of a structure fire the oxygen concentration in the burn room is near normal and smoke contains fewer products of incomplete combustion. As the fire grows, it becomes progressively less oxygenated, resulting in an increase in PICs [16]. This usually coincides with a change in the color of the smoke from light or white smoke to dark or near black smoke. The most dark/black smoke is usually generated just prior to or during flashover of the room where supper heated PICs exit the room and partially combust in a more oxygenated environment. Flashover is defined as the point in a fire where the flames exit the room door and heat release rate of the fire exceeds $1 \mathrm{MW}$.

In this study, extensive sampling and analysis of smoke was performed by collecting separate samples for the early stages of the fire, white smoke, and Black smoke, collected just prior to or during flashover. Smoke was analyzed via: Fourier Transform Infra-red spectroscopy (FTIR), for Volatile Organic Compounds (VOC) via Summa Canister, for semi-volatile organic compound (SVOC) and for polycyclic aromatic hydrocarbons (PAH) via XAD sorbent samplers, and chlorinated and brominated dioxins and furans via XAD sorbent samplers. Previous work on couches and flat panel televisions has shown that we can successfully perform these analyses using an ISO 9705 room or SBI calorimetry apparatus [1, 2]. This experiment also captured heat release and smoke generation data.

\section{Experimental}

A total of 9 room burns were performed for three different furniture configurations, each configuration corresponding to the source of the furnishings (France, United Kingdom, US). The ISO 9705 rooms have interior dimensions of $2.44 \mathrm{~m}$ wide by $3.66 \mathrm{~m}$ deep and $2.44 \mathrm{~m}$ high with interior surfaces lined with type x gypsum board. The test matrix in Table 1 shows the specific condition for each burn experiment detailing the source of the furniture and television and the ignition source size for the experiment. In addition to the 3 cushion couch, chair and flat panel television, each room was fitted with an identical coffee table, end table, curtain, and bookcase obtained from Walmart plus $12 \mathrm{~kg}$ of books. Figure 1 is a Solid Works $\odot$ scale model of the room layout. All of the furniture is to scale and represent exact locations of each item. All rooms were meticulously set-up to ensure comparability of results. The furniture arrangement in the room was not based on a specific standard but was selected to conveniently fit the contents. The lab technicians were allowed to place the furniture in what they thought was the best functional arrangement. Once selected, all subsequent rooms were set up identically with location of items within $\pm 1 \mathrm{~cm}$ of the original setting. Dimensions of furniture and room layout are provided in the supplemental information.

Couches were identical models purchased at IKEA stores in the countries of France, United Kingdom and US. All were purchased in September of 2018 and were the identical model but manufactured to the requirements of the markets where purchased. All of the couches and chairs were the Ektorp 3 seat couch and chair, both Lafollette Beige. Flat panel televisions (FPD) were purchased from 


\section{Table 1}

Testing Matrix for the Nine Room Burns Listing Room Configurations And Ignition Sources with Assigned Test Number and Label for All Subsequent Data and Mass of Test Items

\begin{tabular}{llccccc}
\hline $\begin{array}{l}\text { Test } \\
\text { number }\end{array}$ & $\begin{array}{c}\text { Country } \\
\text { source }\end{array}$ & $\begin{array}{c}\text { Ignition } \\
\text { source }\end{array}$ & $\begin{array}{c}\text { Data } \\
\text { labels }\end{array}$ & $\begin{array}{c}\text { Couch } \\
\text { weight (kg) }\end{array}$ & $\begin{array}{c}\text { Chair } \\
\text { weight (kg) }\end{array}$ & $\begin{array}{c}\text { FPD TV } \\
\text { weight (kg) }\end{array}$ \\
\hline 1 & United Kingdom (GB) & Crib 4 & GB-1 & 60.6 & 35.8 & 17.2 \\
2 & France (FR) & Crib 4 & FR-1 & 61.5 & 36.5 & 14.7 \\
3 & Unite States (US) & Crib 4 & US-1 & 59.6 & 34.5 & 17.2 \\
4 & GB & Crib 5 & GB-2 & 60.8 & 35.2 & 17.2 \\
5 & FR & Crib 5 & FR-2 & 61.0 & 37.0 & 14.7 \\
6 & US & Crib 5 & US-2 & 59.9 & 34.2 & 17.5 \\
7 & GB & Crib 6 & GB-3 & 60.8 & 35.4 & 17.2 \\
8 & FR & Crib 6 & FR-3 & 60.8 & 36.5 & 14.7 \\
9 & US & Crib 6 & US-3 & 60.5 & 34.7 & 17.5 \\
\hline
\end{tabular}

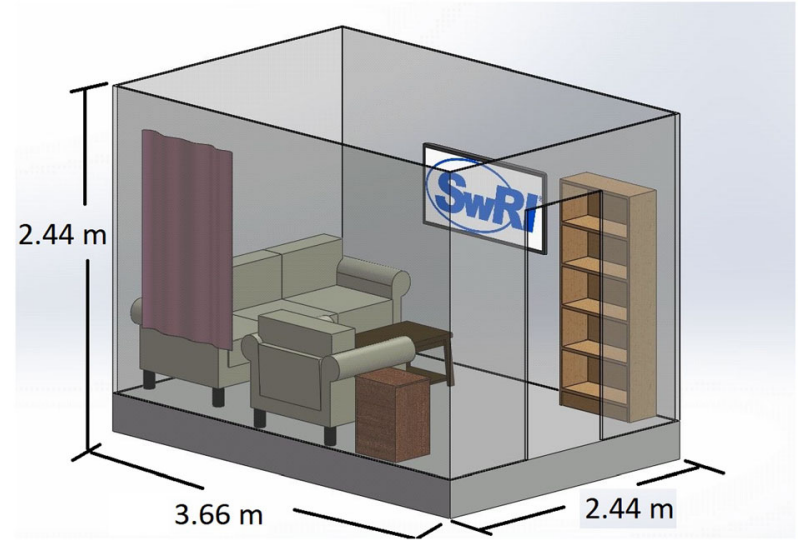

Figure 1. Solidworks drawing of room configuration with the specific layout of furniture, room dimensions shown. The door dimensions are $0.91 \mathrm{~m}$ by $1.98 \mathrm{~m}$.

electronic stores in the three countries, all were $1.4 \mathrm{~m}$ (55 inch) Samsung FPD LED models of as similar design as possible. All appeared to be identical. A sample picture of the couch, chair and television can be seen in Figure 2. Table 2 shows the potential fire retardant elemental analysis. Samples were excised from test article; samples were taken from the plastic casing of the FPD and from all cushion fill materials. Samples were microwave digested with nitric acid, then analyzed via inductively coupled plasma -atomic emission spectroscopy (ICP-AES) for phosphorus (P), and antimony ( $\mathrm{Sb}$ ). Ion Chromatography was used to analyze for $\mathrm{Cl}$ and $\mathrm{Br}$. All of the television cases appear to contain phosphorus-based Fire Retardants. 


\section{Table 2 \\ ICP-AES-the LOQ for Sb was $4.9 \mathrm{mg} / \mathrm{kg}$ and P was $189 \mathrm{mg} / \mathrm{kg}$ with a Precision of $\pm 25 \%$ RSD at the Detection Limit. Cl and Br were Analyzed by Ion Chromatography and had LOQ of 58 ppm}

\begin{tabular}{lllll}
\hline Sample & $\mathrm{mg} / \mathrm{kg} \mathrm{Cl}$ & $\mathrm{mg} / \mathrm{kg} \mathrm{Br}$ & $\mathrm{mg} / \mathrm{kg} \mathrm{P}$ & $\mathrm{mg} / \mathrm{kg} \mathrm{Sb}$ \\
\hline French TV plastic casing & $\mathrm{ND}$ & 98.9 & 8610 & 10.4 \\
French couch cushion loose filling & 135 & $\mathrm{ND}$ & $\mathrm{ND}$ & 189 \\
French couch cushion foam & 1880 & $\mathrm{ND}$ & $\mathrm{ND}$ & $\mathrm{ND}$ \\
British TV plastic casing & $\mathrm{ND}$ & $\mathrm{ND}$ & 11,600 & $\mathrm{ND}$ \\
British couch cushion loose filling & 168 & $\mathrm{ND}$ & $\mathrm{ND}$ & 191 \\
British couch cushion foam & 831 & $\mathrm{ND}$ & 6160 & $\mathrm{ND}$ \\
US TV plastic casing & $\mathrm{ND}$ & $\mathrm{ND}$ & 13,800 & $\mathrm{ND}$ \\
US couch cushion loose filling & 2760 & $\mathrm{ND}$ & $\mathrm{ND}$ & $\mathrm{ND}$ \\
US couch cushion foam & $\mathrm{ND}$ & $\mathrm{ND}$ & $\mathrm{ND}$ & $\mathrm{ND}$ \\
\hline
\end{tabular}

Ignition sources used were purchased from Carr Wood Tech, Mesa Arizona and isopropyl alcohol was purchased as technical grade from Fischer Chemicals.

All experiments were performed in a large oxygen consumption calorimeter that was calibrated before this program. The precision of measurement for the heat release rate $(\mathrm{HRR})$ is $\pm 7 \%$. Smoke density was measured with a laser light source and a photo multiplier tube mounted to the ventilation hood exhaust duct. This method gave a precision of measurement $0.1 \%$ reported as an opacity in $\mathrm{m}^{2} /$ $\mathrm{s}$ as the cross section area and linear flow of the duct. All rooms were equipped with a thermocouple tree located with thermocouples at 0.5, 1.0, 1.5, 2.0 and $2.5 \mathrm{~m}$ in height in the center of the room.

Each burn was started with the ignition source placed in the center of the middle seat cushion with the vertical surface of the source in contact with vertical back cushion. Orientation of the ignition source was the same in all tests. The isopropyl alcohol, $1.4 \mathrm{ml}$, was applied to the crib $30 \mathrm{~s}$ before being placed on the couch and ignited with a propane lighter.

There were two gas sample collection points for each room burn. Each was attached to a separate $4 \mathrm{~m}, 150^{\circ} \mathrm{C}$ heated sample transfer lines constructed of $4.6 \mathrm{~mm}$ ID PTFE tubing and a Thermo Fischer $2 \mathrm{~m}$ path length gas cell. Analysis was performed by a Thermo Fischer iS50 FTIR using a liquid nitrogen cooled DTGS detector. Sampling probes were SS316 stainless steel, $4.6 \mathrm{~mm}$ ID tubing. Sample flow rate was $1.688 \mathrm{~Pa}^{*} \mathrm{~m}^{3} / \mathrm{s}$. The first collection point was from the doorway center at a height of $1.52 \mathrm{~m}$. The second collection point was from the center of the room at a height of $0.457 \mathrm{~m}$. Calibration of the instruments was performed using NIST traceable analytical standards to achieve lower than a $10 \mathrm{ppm}$ limit of detection with an analytical precision of $\pm 5 \mathrm{ppm}$ for most gases. Carbon Dioxide had a detection limit of $500 \mathrm{ppm} \pm 250 \mathrm{ppm}$. The lower precision of carbon dioxide is driven by the extreme range of detection of 500 to 200,000 ppm plus a normal background of $343 \mathrm{ppm}$. The error of measurement for carbon monoxide (CO) is $\pm 20 \mathrm{ppm}$ at $4998 \mathrm{ppm}$, the highest NIST traceable calibration standard 
Table 3

Heat, Smoke and Flashover Data Summary for All 9 Burn Test of the Three Different Country Configurations

\begin{tabular}{lccccccc}
\hline Test & $\begin{array}{c}\mathrm{pHRR} \\
\mathrm{kW}\end{array}$ & $\begin{array}{c}\text { Time to } \\
\mathrm{pHRR}\end{array}$ & $\begin{array}{c}\text { Total } \\
\text { heat } \mathrm{MJ}\end{array}$ & $\begin{array}{c}\text { Max smoke } \\
\mathrm{m}^{2} / \mathrm{s}\end{array}$ & $\begin{array}{c}\text { Time to } \\
\text { max smoke }\end{array}$ & $\begin{array}{c}\text { Total } \\
\text { smoke } \mathrm{m}^{2}\end{array}$ & $\begin{array}{c}\text { Flashover } \\
\text { min:s }\end{array}$ \\
\hline $\begin{array}{l}\text { Summary smoke } \\
\text { US1 }\end{array}$ & 2890 & $6: 24$ & 2134 & 191.5 & $9: 36$ & 62,975 & $5: 00$ \\
US2 & 2922 & $7: 49$ & 2107 & 204.6 & $9: 54$ & 70,517 & $5: 00$ \\
US3 & 2811 & $6: 21$ & 1800 & 216.1 & $9: 00$ & 85,362 & $4: 20$ \\
US Average & 2874 & $6: 51$ & 2014 & 204.1 & $9: 30$ & 72,951 & $4: 46$ \\
\%RSD & $2.0 \%$ & & $9.2 \%$ & $6.0 \%$ & & $15.6 \%$ & \\
GB1 & 2690 & $24: 19$ & 1892 & 189 & $27: 44$ & 33,734 & $22: 37$ \\
GB2 & 2822 & $21: 09$ & 1899 & 204.1 & $21: 09$ & 45,196 & $17: 10$ \\
GB3 & 2499 & $21: 00$ & 1909 & 181 & $20: 25$ & 24,061 & $19: 07$ \\
GB Average & 2670 & $21: 04$ & 1900 & 191.4 & $21: 09$ & 34,330 & $19: 38$ \\
\%RSD & $6.1 \%$ & & $0.45 \%$ & $6.1 \%$ & & $30.8 \%$ & \\
FR1 & 2941 & $6: 29$ & 2300 & 197.6 & $9: 22$ & 72,561 & $5: 00$ \\
FR2 & 3307 & $5: 56$ & 2278 & 209.3 & $9: 11$ & 79,664 & $4: 49$ \\
FR3 & 2848 & $7: 34$ & 2011 & 202.8 & $8: 20$ & 72,101 & $5: 00$ \\
FR Average & 3032 & $6: 39$ & 2196 & 203.2 & $8: 57$ & 74,775 & $4: 56$ \\
\%RSD & $8.0 \%$ & & $7.3 \%$ & $2.9 \%$ & & $5.7 \%$ & \\
\hline
\end{tabular}

used. Actual values seen for $\mathrm{CO}$ are 6 to 12 times higher than the highest standard and therefore have greater error. As a result $\mathrm{CO}$ values were only reported to 3 significant figures. All of the FTIR data in this study that exceeds the highest calibration standard are reported to 3 significant figures to account for potential greater measurement error.

Start of ignition corresponds with the zero time of the calorimeter and the 2 min time of the FTIR data. FTIR data have an additional $20 \mathrm{~s}$ offset with the time of the data from the calorimeter. The FTIR captured a summed scan of 7 spectra every $9 \mathrm{~s}$ over the duration of the test.

Sampling for volatile organic compounds (VOC) was performed using EPA method TO-15. Collection was performed using Summa canisters which collected $6.0 \mathrm{~L}$ of gas over a period of $30 \mathrm{~s}$ through a $4 \mathrm{~m}, 150^{\circ} \mathrm{C}$ heated sample line. All VOC samples were collected via sampling probes that were SS316 stainless steel, $4.6 \mathrm{~mm}$ ID tubing. Probes were located at $1.52 \mathrm{~m}$ in the center of the doorway. Two Summa ${ }^{\mathrm{TM}}$ canisters were collected for each test. The first sample was collected when the white smoke started to exit the door frame, and the second was collected when the dark smoke exited the door frame. Samples were sent to an ISO 17025 and NELAC certified analytical laboratory and analyzed within $24 \mathrm{~h}$. Concentration is reported as parts per billion volume/volume (ppb).

Semi-volatile organic compounds (SVOC), and chlorinated and brominated dioxins and furans were collected through the same sampling lines as the VOC using XAD resin solid sorbent collectors. EPA method 8290a was used for PAH/ SVOC and Method 23 was used for Dioxins and Furans. Continuous sampling with the XAD trains was performed from ignition till extinguishment of the first 


\section{Table 4}

Summary of FTIR Data for the Two Sampling Locations for Each Type of Room Ignited with Crib 4; ND = Non-detect

\begin{tabular}{|c|c|c|c|c|c|c|}
\hline $\begin{array}{l}\text { Chemical/ } \\
\text { test and } \\
\text { location }\end{array}$ & $\begin{array}{l}\text { GB-1 cent } \\
\mathrm{Rm} / \text { time to } \\
\text { peak }\end{array}$ & $\begin{array}{c}\text { GB-1 } \\
\text { door/time } \\
\text { to peak }\end{array}$ & $\begin{array}{l}\text { FR-1 cent } \\
\text { Rm/time to } \\
\text { peak }\end{array}$ & $\begin{array}{l}\text { FR-1 door/- } \\
\text { time to } \\
\text { peak }\end{array}$ & $\begin{array}{l}\text { US- } 1 \text { cent } \\
\text { Rm/time to } \\
\text { peak }\end{array}$ & $\begin{array}{c}\text { US-1 door/ } \\
\text { to peak }\end{array}$ \\
\hline $\mathrm{HCN}$ & ND & $\begin{array}{l}1030 \mathrm{ppm} \\
21.1 \mathrm{~min}\end{array}$ & ND & $\begin{array}{l}1230 \mathrm{ppm} \\
6.1 \mathrm{~min}\end{array}$ & ND & $\begin{array}{l}1600 \mathrm{ppm} \\
6.0 \mathrm{~min}\end{array}$ \\
\hline $\mathrm{SO}_{2}$ & $\begin{array}{l}510 \mathrm{ppm} \\
29.9 \mathrm{~min}\end{array}$ & $\begin{array}{l}646 \mathrm{ppm} \\
29.9 \mathrm{~min}\end{array}$ & $\begin{array}{l}588 \mathrm{ppm} \\
13.9 \mathrm{~min}\end{array}$ & $\begin{array}{l}2300 \mathrm{ppm} \\
13.5 \mathrm{~min}\end{array}$ & $\begin{array}{l}639 \mathrm{ppm} \\
13.5 \mathrm{~min}\end{array}$ & $\begin{array}{l}3300 \mathrm{ppm} \\
13.2 \mathrm{~min}\end{array}$ \\
\hline $\mathrm{CO}$ & $\begin{array}{l}18,200 \mathrm{ppm} \\
23.9 \mathrm{~min}\end{array}$ & $\begin{array}{l}18,000 \mathrm{ppm} \\
23.0 \mathrm{~min}\end{array}$ & $\begin{array}{l}31,000 \mathrm{ppm} \\
12.2 \mathrm{~min}\end{array}$ & $\begin{array}{l}28,000 \mathrm{ppm} \\
6.2 \mathrm{~min}\end{array}$ & $\begin{array}{l}60,800 \mathrm{ppm} \\
8.2 \mathrm{~min}\end{array}$ & $\begin{array}{l}38,200 \mathrm{ppm} \\
8.8 \mathrm{~min}\end{array}$ \\
\hline $\mathrm{NH}_{3}$ & ND & ND & ND & $\begin{array}{l}2500 \mathrm{ppm} \\
8.0 \mathrm{~min}\end{array}$ & ND & $\begin{array}{l}2740 \mathrm{ppm} \\
8.4 \mathrm{~min}\end{array}$ \\
\hline Methane & $\begin{array}{l}1090 \mathrm{ppm} \\
23.7 \mathrm{~min}\end{array}$ & $\begin{array}{l}1700 \mathrm{ppm} \\
23.3 \mathrm{~min}\end{array}$ & $\begin{array}{l}1330 \mathrm{ppm} \\
9.7 \mathrm{~min}\end{array}$ & $\begin{array}{l}31,800 \mathrm{ppm} \\
8.0 \mathrm{~min}\end{array}$ & $\begin{array}{l}1430 \mathrm{ppm} \\
10.1 \mathrm{~min}\end{array}$ & $\begin{array}{l}1930 \mathrm{ppm} \\
7.8 \mathrm{~min}\end{array}$ \\
\hline Ethylene & $\begin{array}{l}378 \mathrm{ppm} \\
23.7 \mathrm{~min}\end{array}$ & $\begin{array}{l}818 \mathrm{ppm} \\
23.3 \mathrm{~min}\end{array}$ & $\begin{array}{l}693 \mathrm{ppm} \\
9.4 \mathrm{~min}\end{array}$ & $\begin{array}{l}1890 \mathrm{ppm} \\
8.0 \mathrm{~min}\end{array}$ & $\begin{array}{l}990 \mathrm{ppm} \\
9.8 \mathrm{~min}\end{array}$ & $\begin{array}{l}2030 \mathrm{ppm} \\
7.8 \mathrm{~min}\end{array}$ \\
\hline $\mathrm{CO}_{2}$ & $\begin{array}{l}13,300 \mathrm{ppm} \\
23.7 \mathrm{~min}\end{array}$ & $\begin{array}{l}87,900 \mathrm{ppm} \\
27.4 \mathrm{~min}\end{array}$ & $\begin{array}{l}12,500 \mathrm{ppm} \\
7.8 \mathrm{~min}\end{array}$ & $\begin{array}{l}33,600 \mathrm{ppm} \\
11.1 \mathrm{~min}\end{array}$ & $\begin{array}{l}14,700 \mathrm{ppm} \\
9.9 \mathrm{~min}\end{array}$ & $\begin{array}{l}95,200 \mathrm{ppm} \\
15.2 \mathrm{~min}\end{array}$ \\
\hline $\mathrm{HCl}$ & $\begin{array}{l}65 \mathrm{ppm} \\
23.9 \mathrm{~min}\end{array}$ & ND & ND & ND & ND & ND \\
\hline
\end{tabular}

test for each country's configuration. Subsequent tests for each country had the XAD sampling run from ignition to the appearance of black smoke. The collection was then switched to a second sampling train that collected from the appearance of black smoke till the end of the test. Sampling rate was $3.376 \mathrm{~Pa}^{*} \mathrm{~m}^{3} / \mathrm{s}$. Analysis of all samples was performed by an EPA certified analytical laboratory, the Analytical and Environmental Chemistry Laboratory of Southwest Research Institute.

The study was originally designed to do incremental ignition on each couch starting with crib 4 . If the couch failed to ignite then crib 5 would be applied to the couch with the middle seat and back cushions inverted. If the couch failed to ignite then a fresh location (un-scorched) would be ignited with crib 6. However, all couch types ignited with crib 4 . As a result each country configuration was initiated with crib 4 for the first three experiment. Crib 5 was used for the second three experiments and crib 6 for the third three experiments. This allowed for a direct comparison of each country to a specific ignition source and the impact on ignition source size on the rate at which an individual country furniture type burned. Crib 4 approximately equals $125 \mathrm{~W}$, crib 5 is approximately $250 \mathrm{~W}$, and crib 6 is approximately $900 \mathrm{~W}$. As a reference to a real-life source, Crib 6 equals 2 pages of double sheet full-size newspaper [7]. Cribs 4, 5 and 6 can be seen in the Figure 3 . 


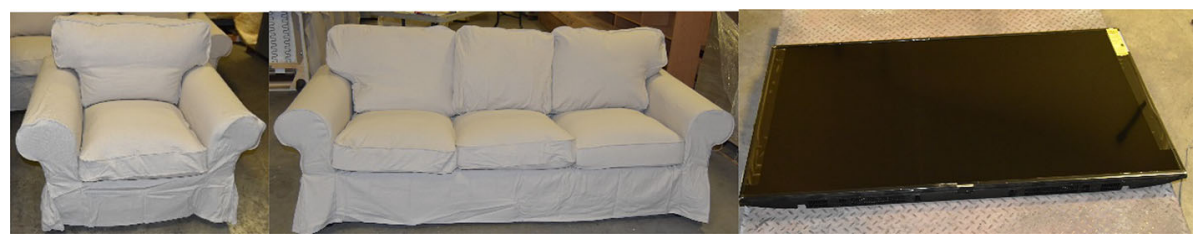

Figure 2. Sample chair, couch and 55 inch television.

\section{Results and Discussion}

\subsection{Qualitative Observations}

The couch ignition on the British configuration was very different from the French and US configuration for all three ignition sources. Very rapid fire growth occurred for the French and US configurations at approximately 3 min into the burn with very little difference between the three ignition sources. All of the French and US configuration burns produced white smoke for a very short period of time. The transition to black smoke stated at the same time as the rapid fire growth, roughly $3 \mathrm{~min}$. Ignition of the second item, the Ektorp Chair, in these room burns was concurrent with flashover at between $4 \mathrm{~min}$ and $5 \mathrm{~min}$. The British configuration required in excess of $15 \mathrm{~min}$ for the fire growth rate to visibly increase. The time between $15 \mathrm{~min}$ to $18 \mathrm{~min}$ showed moderate growth and the post 18 min showing very rapid growth. At the 18 min time frame the smoke in the room transitioned from white to black. As with the French and US rooms, the second item ignited was the Ektorp chair followed immediately by the wooden coffee table. The second items ignited a few seconds prior to the transition to flashover. There was a difference in the timing of the fire growth for the British configuration room burns based on the ignition source.

\subsection{Heat Release Rate Data}

Two different sets of comparisons were performed on smoke and heat release data. The order of events for each country configuration was similar for the timing of flashover and relative intensity of pHHR for each of the three ignition sources. The oxygen consumption calorimetry measurement of HRR rose more slowly for the British configuration compared to both the US and French configurations for all three ignition sources. The measured values of HRR show a minimum of a 15 min delay for the British configurations as seen in Figures 4, 5, and 6. The three configurations versus the ignition size used are shown in separate graphs with: Figure 4 being the crib 4, Figure 5 being the crib 5 and Figure 6 being the crib 6 . To interpret these graphs, the -2 min start time represents the baseline measurements for each test till time zero. All ignition sources were ignited at time zero. Peak heat release rate (PHRR) was highest for the French configuration with crib 5 producing $3.3 \mathrm{MW}$ at $5.9 \mathrm{~min}$. Overall, the US and French configurations were very similar for each ignition source with the largest ignition source, crib 6 , resulting in the lowest pHRR. The crib 5 ignition source did show 


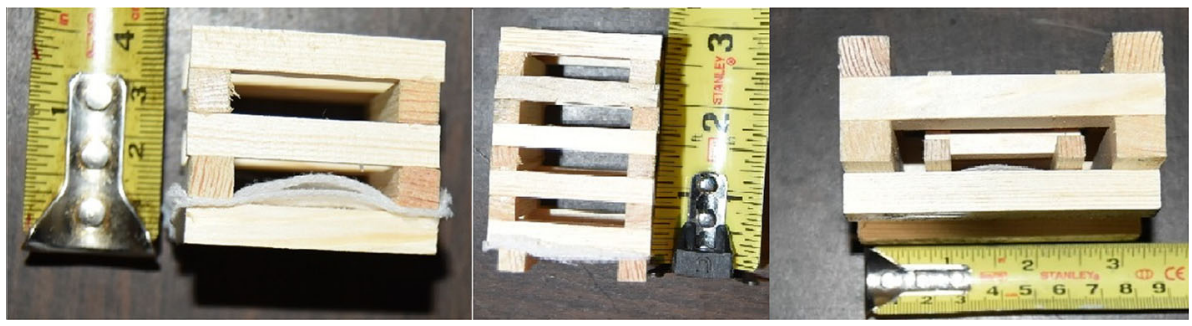

Figure 3. Cribs 4; $5.1 \times 5.1 \times 3.8 \mathrm{~cm}$, crib $5: 3.8 \times 3.8 \times 7.6 \mathrm{~cm}$, and crib $6: 8.9 \times 8.9 \times 5.1 \mathrm{~cm}$ arranged from left to right constructed from light weight Scots Pine wood.

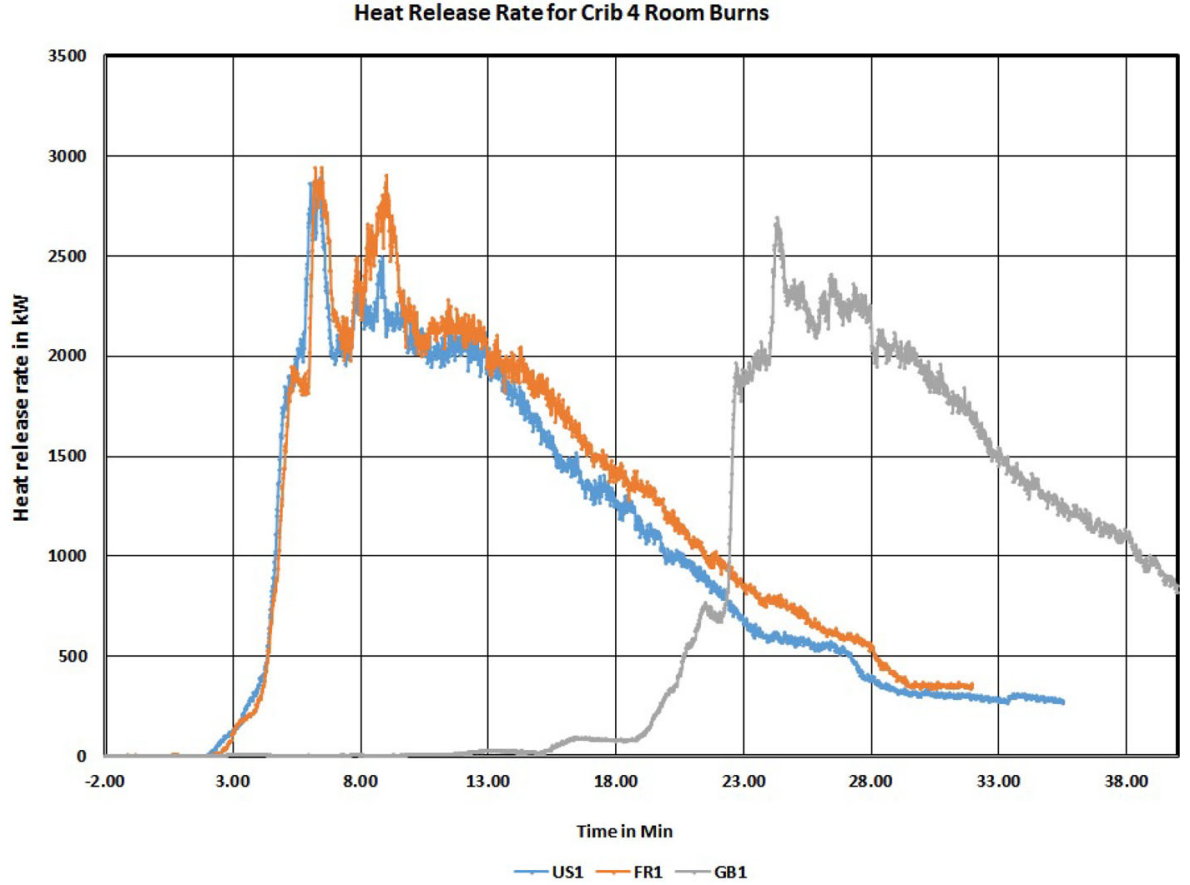

Figure 4. Heat release for all three country configurations using crib 4 ignition source in an oxygen consumption calorimeter measured in kW over the duration of the each burn.

the same timing for the rapid rise of HRR for the US and French rooms but the pHRR was $400 \mathrm{~kW}$ higher for the French room. The British configuration produced a pHRR $320 \mathrm{~kW}$ larger for crib 5 than crib 6 . The data appear to indicate that the crib 5 ignition source may be a more severe exposure than crib 6 based 


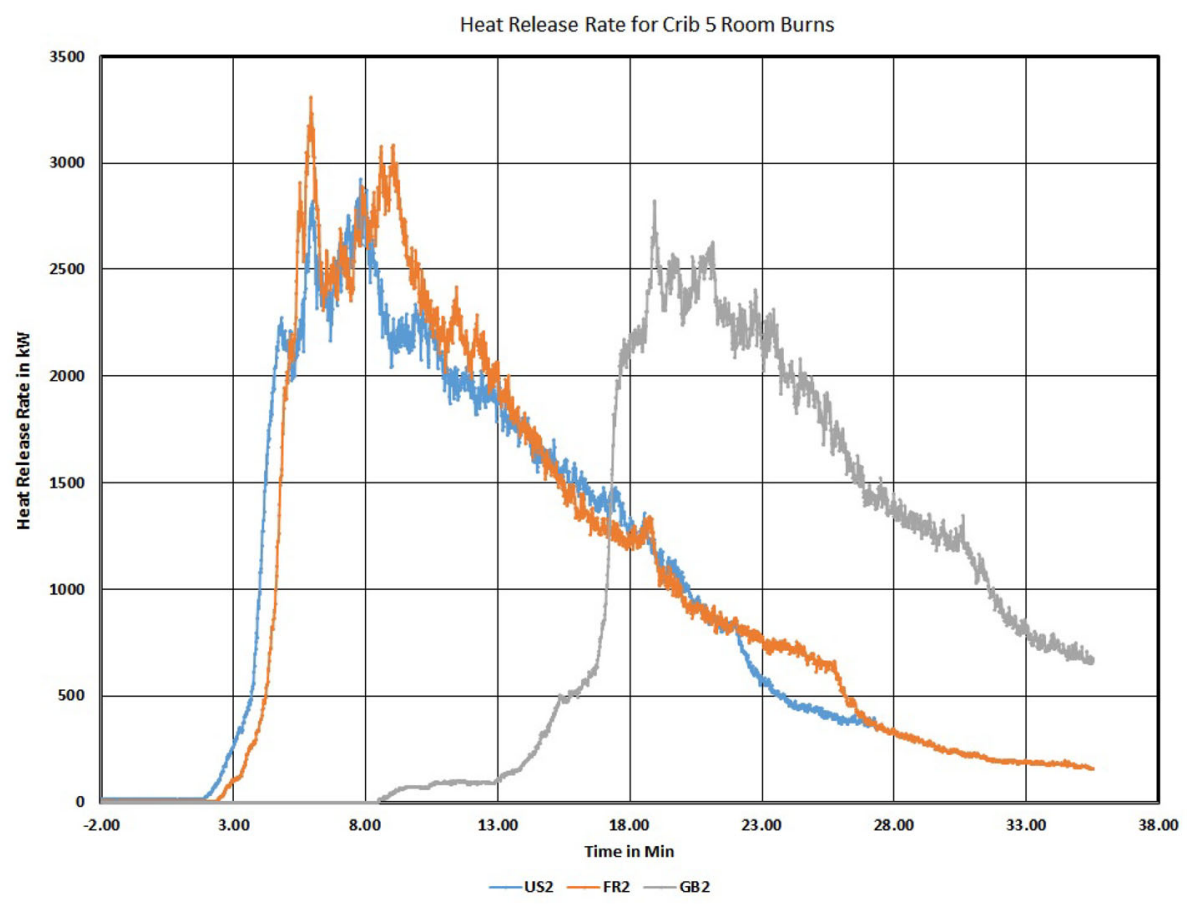

\section{Figure 5. Heat release for all three country configurations using crib 5 ignition source in an oxygen consumption calorimeter measured in kW over the duration of the each burn.}

on both the time to flashover and the intensity of pHRR. Another important observation is that any fire protection present in the French and US configurations is overcome by a $125 \mathrm{~W}$ ignition source resulting in flashover in 4 to $5 \mathrm{~min}$. Also noted is that the British furniture failed to meet the standards set in BS 5852. Cribs 4, 5 and 6 caused the couch to achieve progressive burning and the room to reach flashover. According to BS 5852, the British couch was supposed to resist progressive burning for crib 5. The British couches failed this standard for both cribs 4 and 5. However, the time delay to reach flashover of $22.5 \mathrm{~min}$ does increase the escape time. The wood cribs used were compliant with specification in Section 9.3 of BS 5852-2006.

Examining the HRR data for the British configuration room burns, it appears that the crib 5 used in the test labeled GB-2 in Figure 7 shows a faster ignition and fire growth than for the crib 6 used in GB-3. This phenomenon was also noted in the US configured rooms but the differences were much smaller and the plots are nearly identical. The French configured rooms, however, did not follow this order but again were almost indistinguishable and nearly overlaid each other. The US and French configuration rooms showed little to no sensitivity to the ignition source size. The British couch showed a clear difference in ignition behavior 


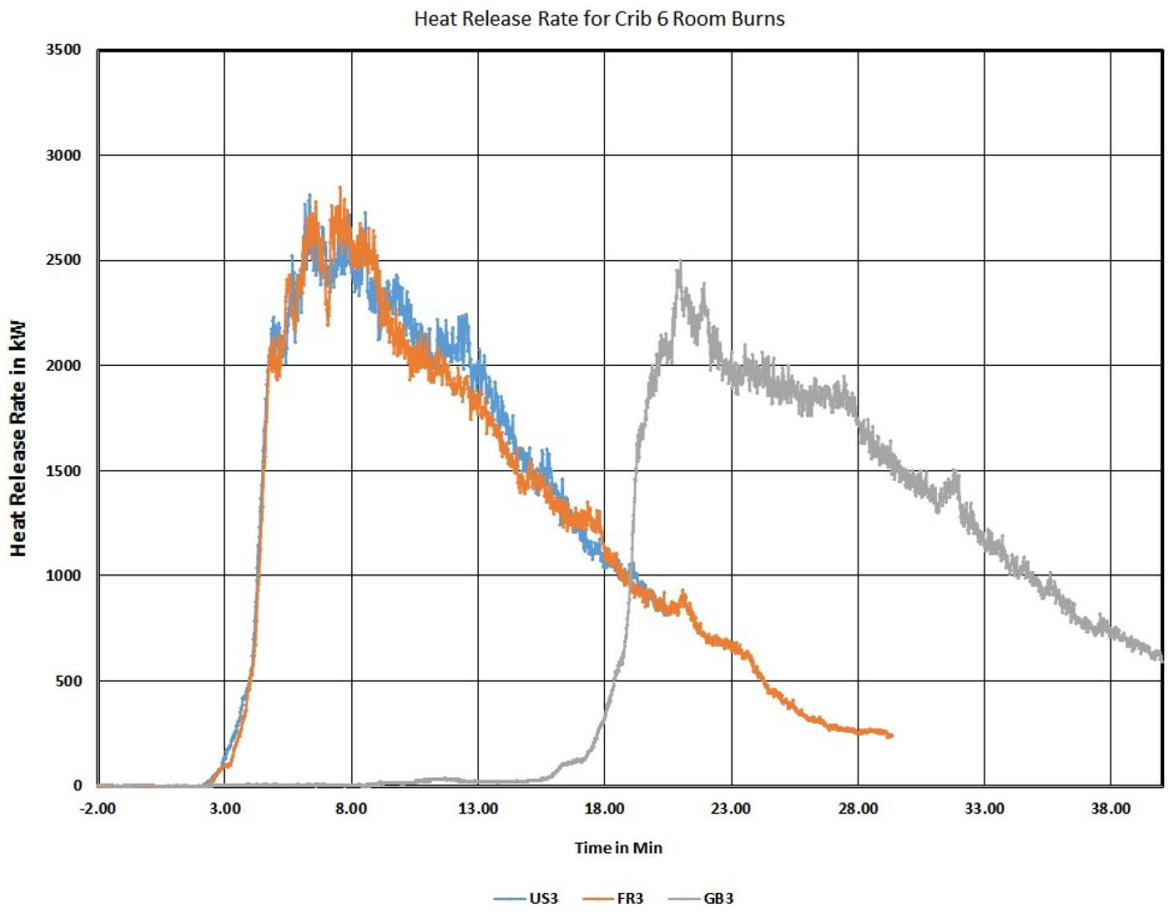

Figure 6. Heat release for all three country configurations using crib 6 ignition source in an oxygen consumption calorimeter measured in kW over the duration of the each burn.

with the different ignition sources with the order of crib 5 and 6 reversed. This may be due to the vertical design of crib 5 and wider design of crib 6 . The energy of crib 5 is applied to a narrow vertical column possibly leading to faster breaching of the cover and access to the foam filling in the cushion and greater convective flow fire spread.

Table 3 summarizes the heat release and smoke data for all 9 of the tests. The pHRR data were very repeatable for each country and significantly different from country to country. Even though progressive ignition sources were used, the pHHR variability between tests of the same configuration was between $2.0 \%$ and $8.0 \%$ relative standard deviation ( $\% \mathrm{RSD})$. The total heat for all configurations and ignition sources ranged from $1800 \mathrm{MJ}$ to $2300 \mathrm{MJ}$ with variabilities for each country configuration of $0.4 \%$ to $9.2 \%$ RSD.

\subsection{Smoke Generation Data}

The total smoke produced for the most fire resistant configuration, the British, was approximately half of that seen for the US and French which were nearly identical. Smoke was measured as opacity in $\mathrm{m}^{2} / \mathrm{sec}$ integrated overtime to give 


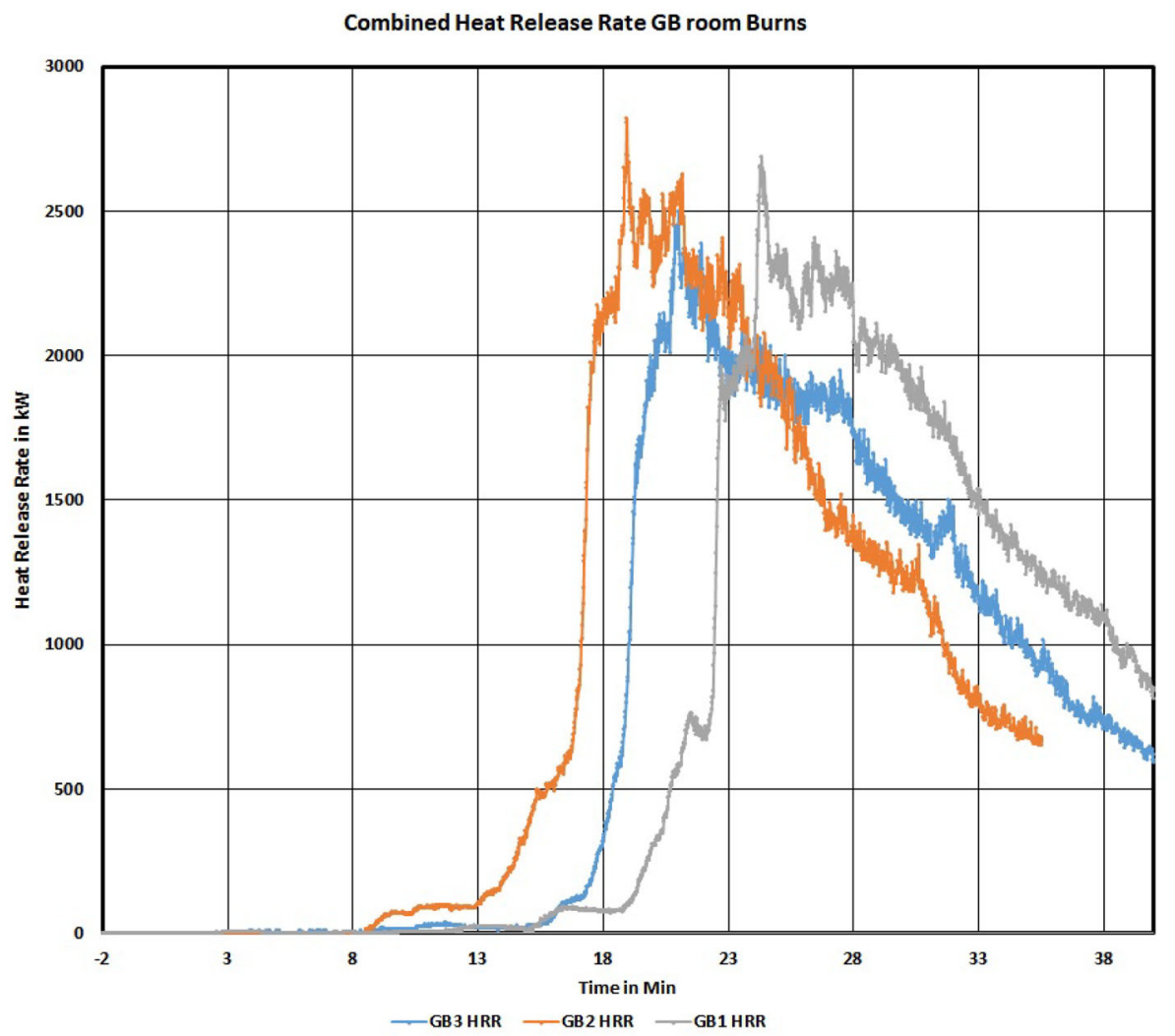

Figure 7. Comparison of HRR for the crib 4, 5, and 6 ignition sources for the British configuration couches with GB-1 using crib 4, GB-2 using crib 5, and GB-3 using crib 6.

unit of $\mathrm{m}^{2}$. The smoke data mimic the results of the heat release rate. Figures 8, 9 and 10 show the comparison of the three country configurations for each crib source. The overall smoke production in the French and US rooms was so high that it overwhelmed the hood draft for the calorimeter and filled the entire $300 \mathrm{~m}^{3}$ laboratory in under 8 min creating near zero visibility (see Figure 11). The British room required between $20 \mathrm{~min}$ and $30 \mathrm{~min}$ to achieve the same level of smoke in the laboratory. The total smoke measurement was not affected by the smoke escaping the ventilation hood because all of the smoke was eventually vented through the hood as shown by the long tails in each of the smoke plots in Figures 8, 9 and 10. However the total smoke measured for French and US configurations was twice that measures for the British configuration, as shown in Table 3. The step like function seen for the US and French rooms in Figures 8, 9, and 10 was caused by over ranging of the smoke detector and is an artifact of the software. The drop in the smoke data for the British room in Figure 8 is a real event. 


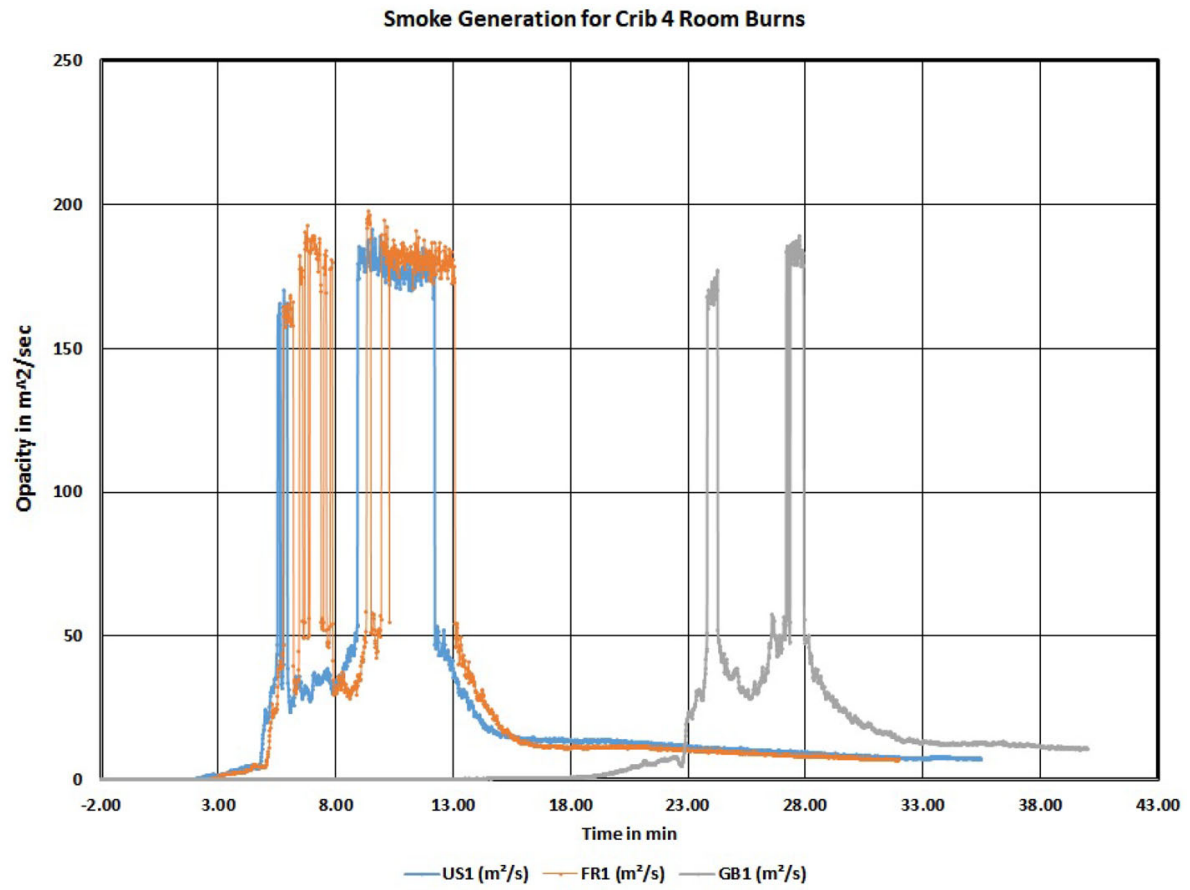

Figure 8. Smoke generation for French, US and British room configurations using crib 4 ignition. Smoke is measured in $\mathrm{m}^{2} / \mathrm{s}$ over the duration of the test.

The room was observed to be opaque from 22 min to $23 \mathrm{~min}$ then burned clear from between $23 \mathrm{~min}$ and $25 \mathrm{~min}$. The smoke then transitioned back to opaque.

All of the rooms initially produced white smoke as shown in Figure 12 but transitioned to dense black smoke shown in Figure 11. Transition to black smoke occurred prior to reaching flashover as the oxygen level in the room dropped coincident to the higher heat release rate. Figure 12 also shows the exact location of all of the sample collection points and the thermocouple tree. The white smoke is difficult to see in Figure 12 if viewed in black and white but clearly visible in color. The white smoke is stratified approximately $0.5 \mathrm{~m}$ above the top of the couch.

\subsection{Chemical Composition of Smoke}

The chemical composition of the smoke varied widely with the phase of the fire. FTIR data were acquired for all 9 of the room burns. Data were acquired for 2 min prior to ignition to provide a pre-testing background. At the 2 min mark of each series collection, the room was ignited resulting in an immediate detection of carbon dioxide $\left(\mathrm{CO}_{2}\right)$, confirming that the system was functioning properly. There 


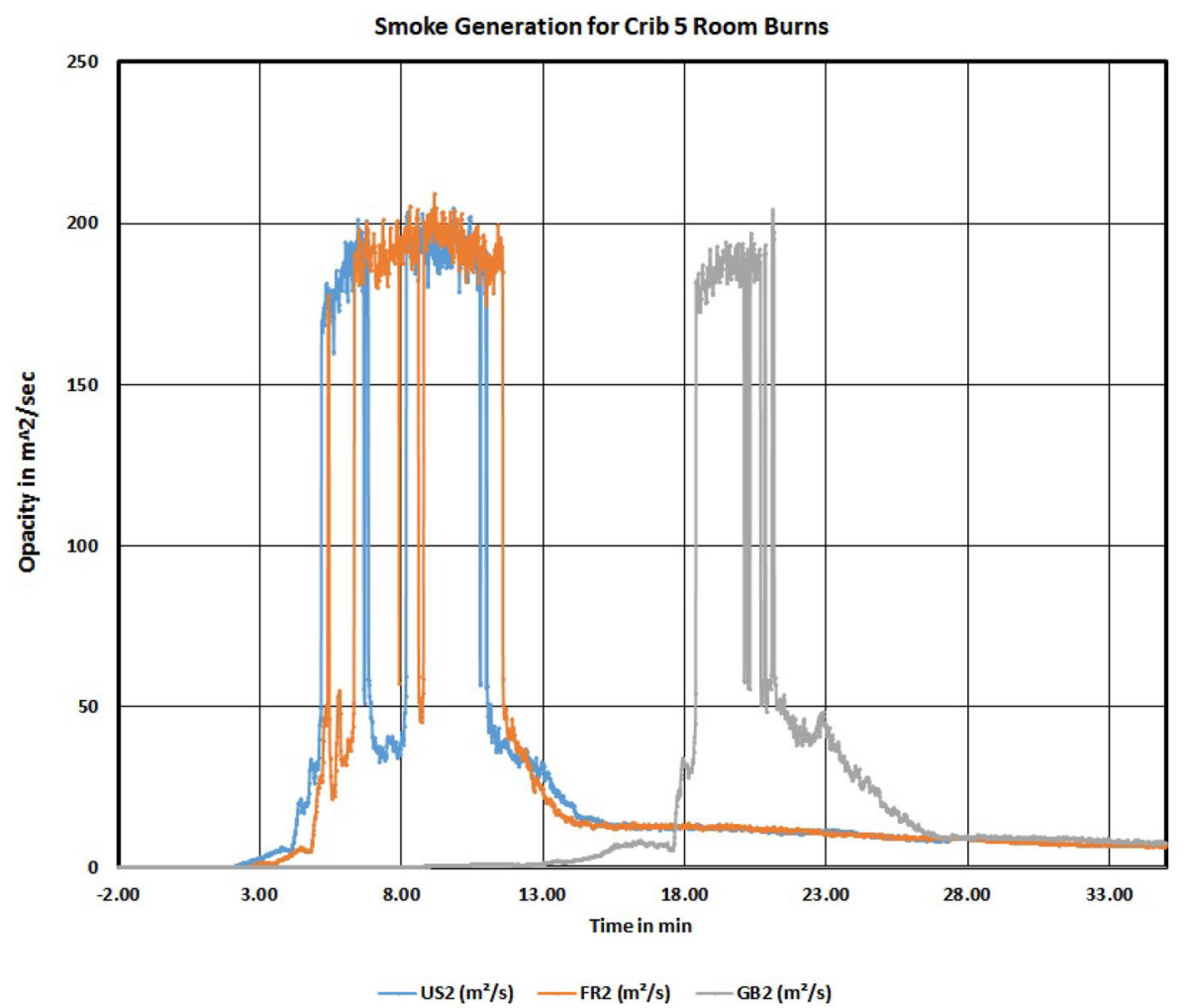

Figure 9. Smoke generation for French, US and British room configurations using crib 5 ignition. Smoke is measured in $\mathrm{m}^{2} / \mathrm{s}$ over the duration of the test.

was an approximate $20 \mathrm{~s}$ delay from sample collection to the read out on the spectrometer due to the length of the sampling line and volume of the $2 \mathrm{~m}$ gas cell. The time delay and the 2 min baseline are already subtracted in the time data shown in Table 4. Summary of the FTIR data is shown in Table 4 for the crib 4 burns of each configuration. The FTIR data for the remaining crib tests is very similar and can be found in the supplemental materials.

All of the rooms produced hydrogen cyanide $(\mathrm{HCN})$ which has an immediately dangerous to life and health (IDLH) value of $50 \mathrm{ppm} \mathrm{[17]} \mathrm{and} \mathrm{was} \mathrm{detected} \mathrm{at} \mathrm{the}$ door but not in the center of the room. The room center is measured at a height of $0.457 \mathrm{~m}$ from the floor below the smoke layer which may account for this difference. The British configuration produced a peak of $1030 \mathrm{ppm}$ at $21 \mathrm{~min} 6 \mathrm{~s}$; this was the lowest concentration of HCN collected in any of the three room configurations. The French configuration produced $1230 \mathrm{ppm}$ at $6 \mathrm{~min} 6 \mathrm{~s}$ and the US room produced $1600 \mathrm{ppm}$ at $6 \mathrm{~min}$. Another interesting result was that sulfur dioxide $\left(\mathrm{SO}_{2}\right)$ which has an IDLH of $100 \mathrm{ppm}$ [17] was produced in all 9 room 


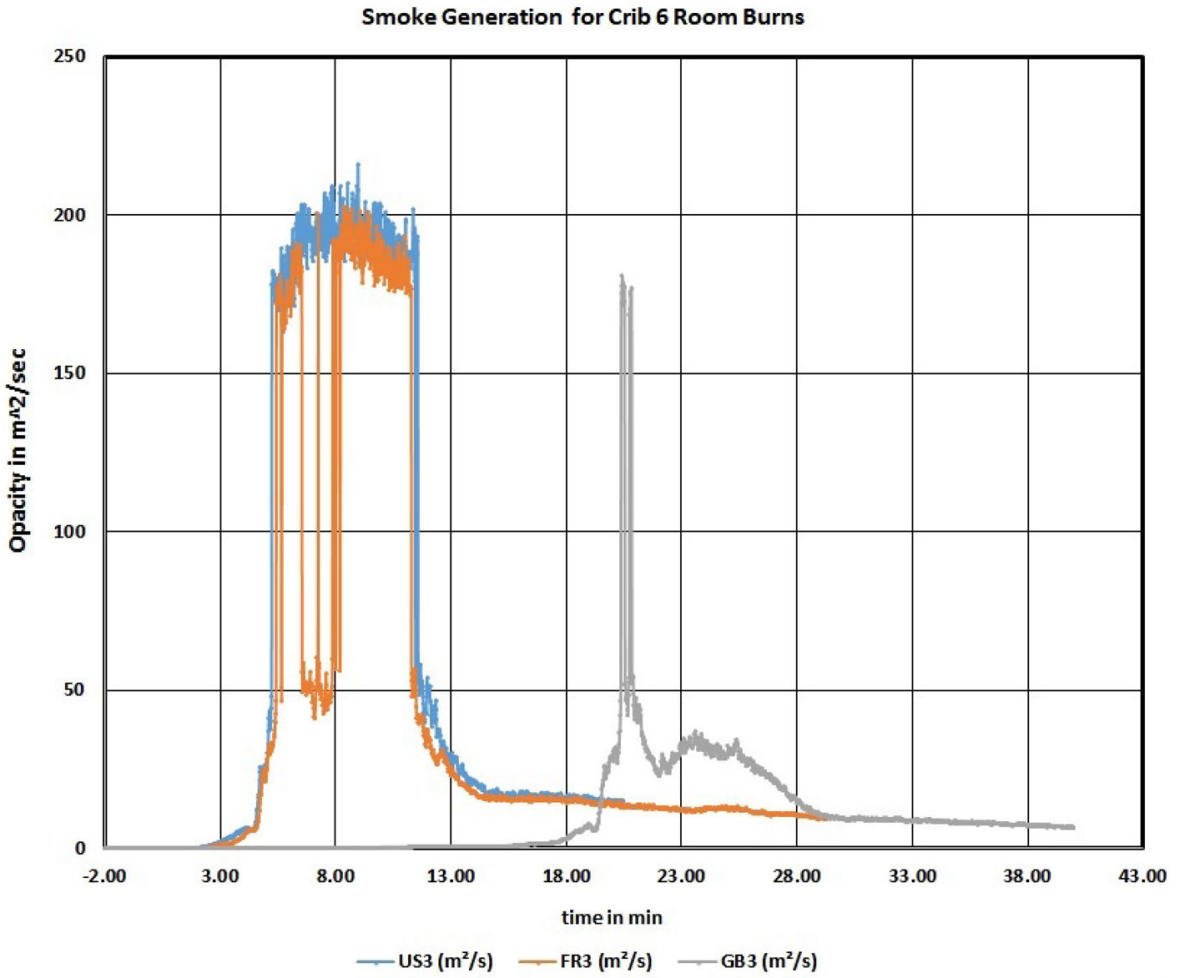

Figure 10. Smoke generation for French, US and British room configurations using crib 6 ignition. Smoke is measured in $\mathrm{m}^{2} / \mathrm{s}$ over the duration of the test.

burns and was detectable in the center of the room and at the doorway. The detection of $\mathrm{SO}_{2}$ occurred after the foam of the furniture had been consumed and the wooden composition of furniture was the primary fuel. Ammonia $\left(\mathrm{NH}_{3}\right)$ which has an IDLH of $300 \mathrm{ppm}$, was only detected in the French and US room burns at the doorway with values of 2500 and $2740 \mathrm{ppm}$, respectively. Ammonia detection also occurred after transition to flashover.

Figure 13 shows the full spectrum of the French configuration FR-1 room burn measured at $1.52 \mathrm{~m}$ height in the doorway. In the spectra, $\mathrm{HCN}$ and carbon monoxide $(\mathrm{CO})$ were clearly visible at high concentration. This is the gas measurement at approximately $1 \mathrm{~min}$ after flashover or $6.5 \mathrm{~min}$ after ignition of the crib 4 . $\mathrm{CO}_{2}$ and water represent the majority of the peaks; however, chain scission fragments of the polymers were present with the ethylene $\left(\mathrm{C}_{2} \mathrm{H}_{4}\right)$ and methane $\left(\mathrm{CH}_{4}\right)$ peaks. Ammonia $\left(\mathrm{NH}_{3}\right)$ was also seen around the ethylene peak between $900 \mathrm{~cm}^{-}$ ${ }^{1}$ and $1000 \mathrm{~cm}^{-1}$. Figure 14 shows the only detection of hydrogen chloride $(\mathrm{HCl})$ as well as detection of $\mathrm{SO}_{2}$ in a room burn, occurring at 30 min into the GB-1 


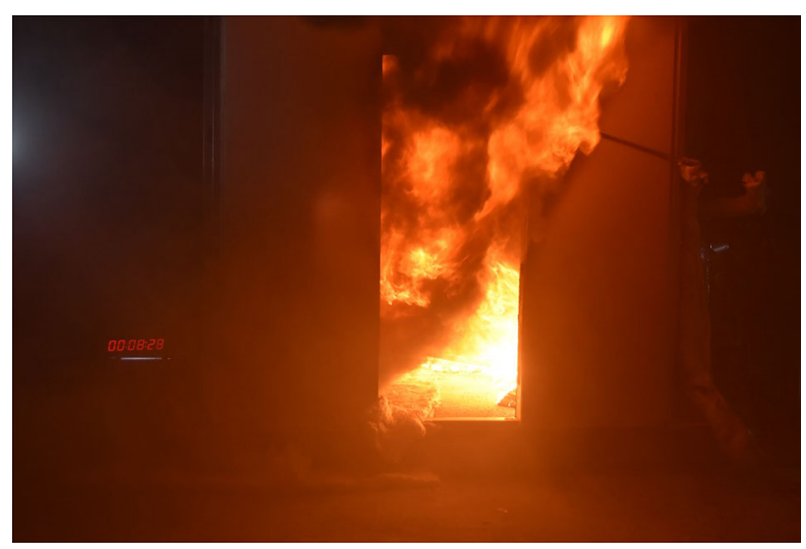

\section{Figure 11. US-2 Room at 8:28, $300 \mathrm{~m}^{3}$ laboratory has filled with smoke. Room is in flashover with all contents burning and PICs escaping the room faster than the ventilation hood could capture.}

room burn. The high concentration of $\mathrm{HCl}$ indicated earlier in the trace was due to interference from the ethylene peak. Only the smaller peaks at time 32.9 and 35.4 min were authenticated as $\mathrm{HCl}$ by manual examination of each spectra in the series. Corrected for the elevated baseline, the concentration in both cases was approximately $65 \mathrm{ppm}$ for $\mathrm{HCl}$ which is near its IDLH value of $50 \mathrm{ppm}$ [17]. Hydrogen Bromide $(\mathrm{HBr})$ was not detected in any of the room burns.

Also in Figure 14 is the confirmation of $\mathrm{SO}_{2}$ in the spectra with resonances centered on $2500 \mathrm{~cm}^{-1}$. The main resonances for $\mathrm{SO}_{2}$ are found between $1300 \mathrm{~cm}^{-1}$ and $1400 \mathrm{~cm}^{-1}$, but these peaks were often buried in the water peaks and other organic molecules making quantitation in that region more difficult.

The 22 min run up to the flashover for the GB-1 burns produced very little or no narcotic gases such as $\mathrm{CO}$ and $\mathrm{HCN}$. At 22 min into the burn, shown as approximately $24 \mathrm{~min}$ on the time scale in Figure 14, high concentrations of CO, HCN and organic vapors were detected at the doorway. Conversely, the burns of both the French and US configurations produced these toxic emissions very early in the fire. High levels of HCN (1234 ppm and $1600 \mathrm{ppm})$ and CO (28,000 ppm and $38,200 \mathrm{ppm}$ ) were detected between $6 \mathrm{~min}$ and $8 \mathrm{~min}$ at the doorway of the burn room. Comparison of the gas concentration plots in the top pane of Figures 13 and 14 show the significant time difference for fire gas production. There is a shift from $3 \mathrm{~min}$ to $23 \mathrm{~min}$ between the French and the British configurations.

For the VOC collection and analysis, the British configuration rooms had a sufficient period of white smoke, $17 \mathrm{~min}$ or longer, to ensure that the samples were clearly separated white from black. The French and US rooms had less than 3 min where white smoke was produced followed by rapid transition to black smoke and flashover. For the shorter duration white smoke periods some of the transition to black smoke may have been trapped in the white smoke samples. Of the 65 compounds that are calibrated for the VOC analysis, 24 were detected in at 


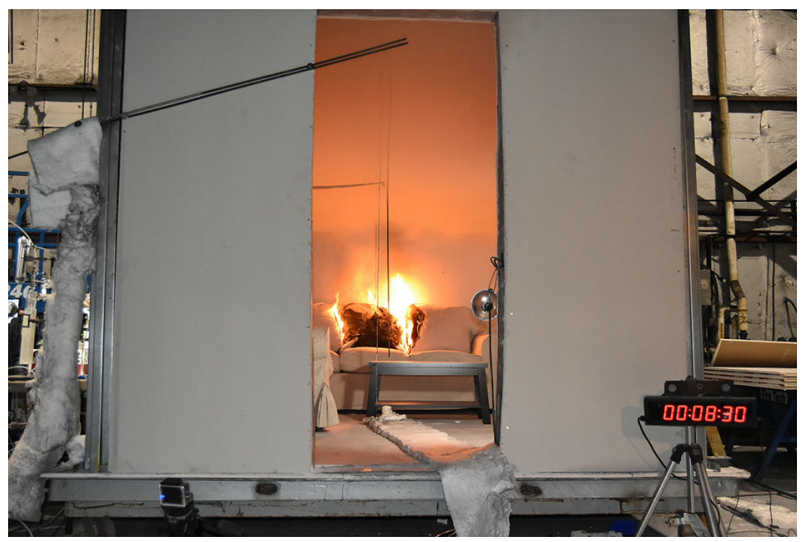

Figure 12. CB-2 at 8:30, white smoke stratified at $1 \mathrm{~m}$ no leakage
from hood. This is the same time as that shown in Fig. 11 and
highlights the difference between British and French rooms.

least one of the 18 samples collected. After conversion to black smoke, the number of analytes and their concentrations of analytes increased significantly. Chlorinated hydrocarbons were detected in all room configurations and all tests. However, only the British configurations produced 1, 2-dichloro-propane, a decomposition product associated with some phosphorus containing fire retardants.

Acrolein was detected in both white and black smoke above acutely toxic levels. Levels increase 10 fold when transition to black smoke occurred. The highest detected concentration of acrolein was detected post-flashover in the US room configuration. Benzene was also present in the white smoke at about $1 \mathrm{ppm}$; however, the black smoke contained 20 to $50 \times$ that of the white smoke. The OSHA Short Term exposure limit is $5 \mathrm{ppm}$ for Benzene [17]. The highest values of benzene where found post-flashover in the French configured rooms in Test FR-1 at $50 \mathrm{ppm}$ with a limit of quantification (LOQ) of $0.001 \mathrm{ppm}$.

In conjunction with the VOC analysis, a list of tentatively identified compounds (TIC) was generated with approximate concentrations. Allyl chloride was detected in two of the samples for the British rooms at about $100 \mathrm{ppb}$, ST equals $2 \mathrm{ppm}$ [17]. This may indicate the presence of one of the tris-chloropropyl-phosphonate FRs. Most of the chemicals detected were monomers and break down product of poly-isocyanate foams or acrylonitrile-butadiene-styrene polymers (ABS). The highest detected TICs were siloxanes with small quantities detected in the British room configurations but up to $41,000 \mathrm{ppb}$ were detected post-flashover in the French furnished rooms. The most likely source of the siloxanes was the 55 inch flat panel televisions in the room [1]. The VOC data can be found in the supplemental information.

Semi-volatile organic compounds (SVOC) were collected for the total fire for burns GB-1, FR-1 and US-1 where XAD cartridges were collected at 


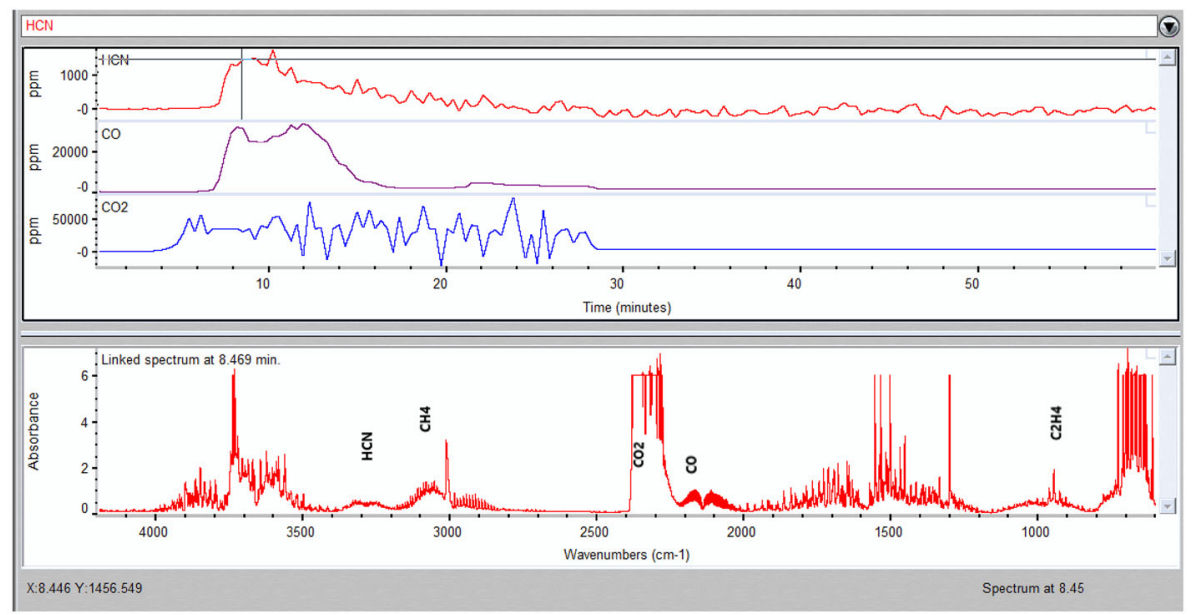

\section{Figure 13. French configuration FR-1 burn FTIR spectrum representing 6 min into the burn and 1 min after flashover. Sampling location was the doorway and key signals are labeled with compound identity.}

3.376 $\mathrm{Pa} * \mathrm{~m}^{3} / \mathrm{s}$ over the duration of the tests. For the second and third burn of each configuration, two XAD cartridges were collected pre and post flashover. The first cartridge for the period of white smoke was initiated with the start of the FTIR collection and terminated at the transition to black smoke. The second cartridge was initiated at the point of heavy black smoke emission. Some carryover, especially in the FR2 and FR3 rooms, may have occurred because the transition time. Table 5 summarizes the data produced in the tests where white and black smoke where measured separately. The only chemicals included in Table 5 are those detected in at least one of the samples in each country configuration. Samples were measured in micrograms of material captured on the cartridge and converted to concentrations by using flow rate and time of collection. The British configuration rooms (GB-2 and 3) had fewer types of PAH, at lower concentration, and of lower molecular weight for both white and black smoke. The US and French rooms contained higher molecular weight and greater toxicity $\mathrm{PAH}$ at orders of magnitude higher concentration. The PAH shown in Table 5 are italicized.

The white smoke contains considerably less SVOC than the black smoke with the exception of the French rooms. The French rooms transitioned to black smoke very quickly and some of the black smoke was collected on the white smoke XAD collector for Experiment FR-3. The lower production of high molecular weight $\mathrm{PAH}$ in fire retardant protected materials was first reported by Blomqvist [18] and is consistent with the data obtained in these experiments. In addition to the standard SVOC chemicals analyzed on the XAD cartridges, these were also analyzed for TICs. The chemicals detected are similar to those detected 


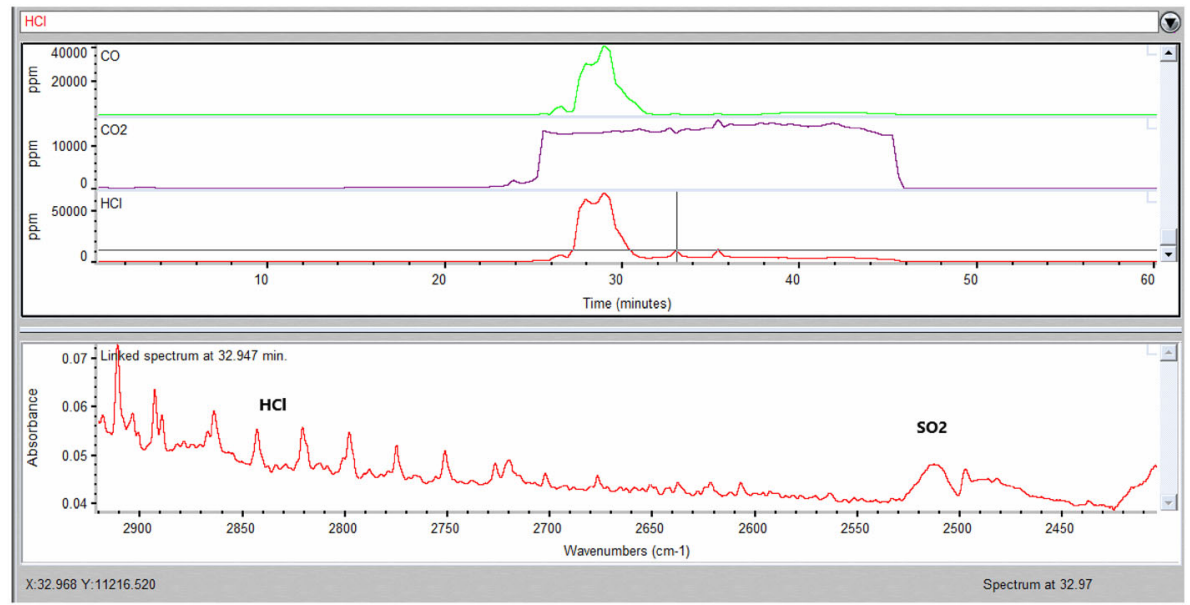

Figure 14. British configuration $\mathrm{CB}-1$ burn at $30.9 \mathrm{~min}$ from ignition and 6 min after flashover. This is an expansion and amplification of the region where $\mathrm{HCl}$ and $\mathrm{SO}_{2}$ signals are quantifated. This sample was collected from the middle of the room.

in the VOC and VOC TIC analysis. All of the SVOC and TIC data is provided in the supplemental materials.

Chlorinated dioxins and furans were also collected using XAD collectors from the same sample lines used to collect SVOC. Table 6 lists only those chlorinated dioxins and furans detected during the respective room burns. All other values were below the limit of detection. Of the concentrations that were detected, however, all were below the level of quantitation. All three of the French configured rooms produced chlorinated dioxins. One out of three British burns produced a chlorinated furan. The one detection for the British room occurred in the black smoke collected after the transition to flashover.

The detection in the white smoke may have been caused by some of the black smoke being captured as a result of the very rapid transition from white to black smoke in these rooms. Brominated dioxins and furans were also measured for all burns. Very low levels of brominated dioxins and furans were detected during all 9 tests. All of the detections are below the level of quantitation except for the GB2 Black smoke sample which had 1,2,3,4,6,7,8-HpBDF at $15.96 \mathrm{pg}$. Table 7 shows only those tests where the brominated dioxins and furans were measured. All other values were non-detect. All of the Chlorinated and brominated dioxin and furan data is available in the supplemental materials.

The concentration and variety of chemical components of smoke was higher in the French and US rooms then the British rooms. This is evident in Table 4 for the narcotic gases $\mathrm{HCN}$ and $\mathrm{CO}$ collected in the doorway. The PAHs in Table 5 show higher concentrations for the higher molecular weight and more chronically toxic compounds like benzo[a]pyrene and chrysene for the French and US rooms. 
Table 5

SVOC Data for Room Burns of British, French, and US Room Configurations with White and Black Smoke Comparison; ND = Nondetect. The Limit of Detection was 5 Micrograms per XAD Cartridge for All Analytes

\begin{tabular}{|c|c|c|c|c|}
\hline $\begin{array}{l}\text { Sample ID } \\
\text { Compound }\end{array}$ & $\begin{array}{l}\text { GB-2 SVOC } \\
\text { White } \\
\text { micrograms } / \mathrm{m}^{3}\end{array}$ & $\begin{array}{l}\text { GB-3 SVOC } \\
\text { White } \\
\text { micrograms } / \mathrm{m}^{3}\end{array}$ & $\begin{array}{c}\text { GB-2 SVOC } \\
\text { Black } \\
\text { micrograms } / \mathrm{m}^{3}\end{array}$ & $\begin{array}{c}\text { GB-3 SVOC } \\
\text { Black } \\
\text { micrograms } / \mathrm{m}^{3}\end{array}$ \\
\hline Phenol & ND & 421 & 500 & 155 \\
\hline Naphthalene & ND & 1684 & 10,400 & 6667 \\
\hline 2-Methylnaphthalene & ND & ND & 106 & ND \\
\hline Acenaphthylene & ND & 189 & 1800 & 1176 \\
\hline Dibenzofuran & ND & ND & 78 & ND \\
\hline Fluorene & ND & ND & 68 & ND \\
\hline Phenanthrene & ND & ND & 520 & 145 \\
\hline Anthracene & ND & ND & 62 & ND \\
\hline Fluoranthene & ND & ND & 194 & 67 \\
\hline Pyrene & ND & ND & 260 & 143 \\
\hline Acetophenone & ND & 97 & 174 & 63 \\
\hline $\begin{array}{l}\text { Sample ID } \\
\text { Compound }\end{array}$ & $\begin{array}{l}\text { US-2 SVOC } \\
\text { White } \\
\text { micrograms } / \mathrm{m}^{3}\end{array}$ & $\begin{array}{l}\text { US-3 SVOC } \\
\text { White } \\
\text { micrograms } / \mathrm{m}^{3}\end{array}$ & $\begin{array}{c}\text { US-2 SVOC } \\
\text { black } \\
\text { micrograms } / \mathrm{m}^{3}\end{array}$ & $\begin{array}{c}\text { US-3 SVOC } \\
\text { Black* } \\
\text { micrograms } / \mathrm{m}^{3}\end{array}$ \\
\hline Pyridine & ND & ND & 949 & 471 \\
\hline Phenol & ND & 590 & 385 & 276 \\
\hline Naphthalene & ND & 6800 & 69,231 & 16,176 \\
\hline 2-Methylnaphthalene & ND & ND & 1256 & 106 \\
\hline Acenaphthylene & ND & 460 & 4615 & 824 \\
\hline Dibenzofuran & ND & ND & 564 & 126 \\
\hline Fluorene & ND & ND & 410 & ND \\
\hline Phenanthrene & ND & ND & 2821 & ND \\
\hline Anthracene & ND & ND & 513 & ND \\
\hline Fluoranthene & ND & ND & 1103 & ND \\
\hline Pyrene & ND & ND & 1179 & ND \\
\hline Benzo[a]anthracene & ND & ND & 190 & ND \\
\hline Chrysene & ND & ND & 241 & ND \\
\hline Benzo(b)fluoranthene & ND & ND & 231 & ND \\
\hline Benzo[a]pyrene & ND & ND & 238 & ND \\
\hline Indeno $[1,2,3-c d]$ pyrene & ND & ND & 156 & ND \\
\hline Benzo $[g, h, i]$ perylene & ND & ND & 185 & ND \\
\hline $\begin{array}{l}\text { Sample ID } \\
\text { Compound }\end{array}$ & $\begin{array}{c}\text { FR-2 SVOC } \\
\text { Black } \\
\text { micrograms } / \mathrm{m}^{3}\end{array}$ & $\begin{array}{c}\text { FR-3 SVOC } \\
\text { black } \\
\text { micrograms } / \mathrm{m}^{3}\end{array}$ & $\begin{array}{l}\text { FR-2 SVOC } \\
\text { White } \\
\text { micrograms } / \mathrm{m}^{3}\end{array}$ & $\begin{array}{c}\text { FR-3 SVOC } \\
\text { White** } \\
\text { micrograms } / \mathrm{m}^{3}\end{array}$ \\
\hline Pyridine & 3167 & 767 & ND & 1438 \\
\hline Aniline & 400 & ND & ND & 171 \\
\hline Phenol & 4833 & 6333 & ND & 375 \\
\hline m-cresol \& p-cresol & 317 & 533 & ND & - \\
\hline
\end{tabular}




\section{Table 5}

continued

\begin{tabular}{lclll}
\hline $\begin{array}{l}\text { Sample ID } \\
\text { Compound }\end{array}$ & $\begin{array}{c}\text { FR-2 SVOC } \\
\text { Black } \\
\text { micrograms/m }\end{array}$ & $\begin{array}{c}\text { FR-3 SVOC } \\
\text { black } \\
\text { micrograms/m }\end{array}$ & $\begin{array}{c}\text { FR-2 SVOC } \\
\text { White } \\
\text { micrograms/m }\end{array}$ & $\begin{array}{c}\text { FR-3 SVOC } \\
\text { White** } \\
\text { micrograms/m } / \mathrm{m}^{3}\end{array}$ \\
\hline $\begin{array}{l}\text { Naphthalene } \\
\text { 2-Methylnaphthalene }\end{array}$ & 141,667 & 18,333 & 173 & 35,417 \\
Acenaphthylene & 1917 & 500 & ND & 396 \\
Dibenzofuran & 16,667 & 3500 & ND & 2500 \\
Fluorene & 492 & ND & ND & 229 \\
Phenanthrene & 700 & ND & ND & 185 \\
Anthracene & 4500 & 2000 & ND & 1854 \\
Fluoranthene & 700 & ND & ND & 333 \\
Pyrene & 1667 & 2000 & ND & 875 \\
Benzo[a]anthracene & 1917 & 2167 & ND & 1104 \\
Chrysene & 208 & 600 & ND & 115 \\
Benzo(b)fluoranthene & 242 & 717 & ND & 156 \\
Benzo[a]pyrene & 292 & 867 & ND & 138 \\
Indeno[1,2,3-cd]pyrene & 342 & 750 & ND & 125 \\
Benzo[g,h,i]perylene & 233 & 600 & ND & 73 \\
Acetophenone & 292 & 583 & ND & 110 \\
\hline
\end{tabular}

*Line blockage occurred during sample collection and numbers are likely lower than actual concentration

**Some black smoke was sampled due to late switching of samplers and very fast transition to black smoke

Both the chlorinated and brominated dioxins and furans were very low across the board with no significant levels detected. The measured values for all black smoke far exceed those detected in white smoke. As a result the French and US configuration, which produced almost twice the quantity of total smoke, produced the highest quantities of toxic components much earlier in the combustion process. The concentration data by themselves, however, do not enable prediction of toxicity to humans. Synergistic, additive, and/or antagonistic effects make prediction of toxicity highly uncertain without actual toxicity testing.

\section{Conclusions}

In this study the most fire retarded furniture burned more slowly and produced less acutely toxic smoke and less total smoke than the furnishings with poor protection from fire. This is logical as more mass is consumed during the oxygen deficient period of the burn when highly toxic black smoke is produced as a result of incomplete combustion. Low levels of oxygen are indicated by the high concentrations of $\mathrm{CO}$ and $\mathrm{HCN}$, produced in significantly higher yields during under ventilated flaming. The French and US room configurations were less fire retarded and produced more total black smoke containing more and higher molecular weight $\mathrm{PAH}$, as shown in the SVOC data. The VOC data also supported this trend for benzene, toluene and acrolein. The smoke from the British configuration was less 


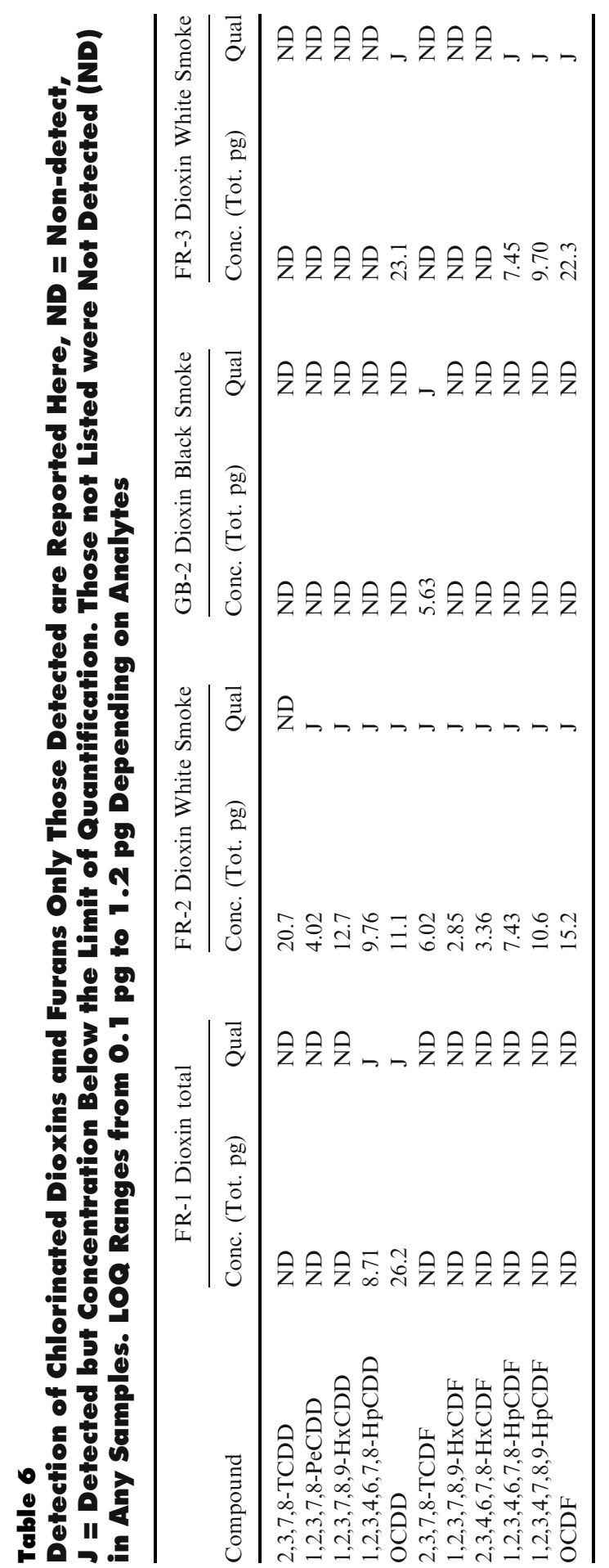




\begin{abstract}
Table 7
Defection of Brominated Dioxins and Furans Only Those Detected are Reported Here, ND = Non-detect, $J$ = Detected but Concentration Below the Limit of Quantification. Those not Listed were Not Detected (ND) in Any Samples. LOQs Ranged from 0.1 pg to 1.2 pg depending on analytes
\end{abstract}

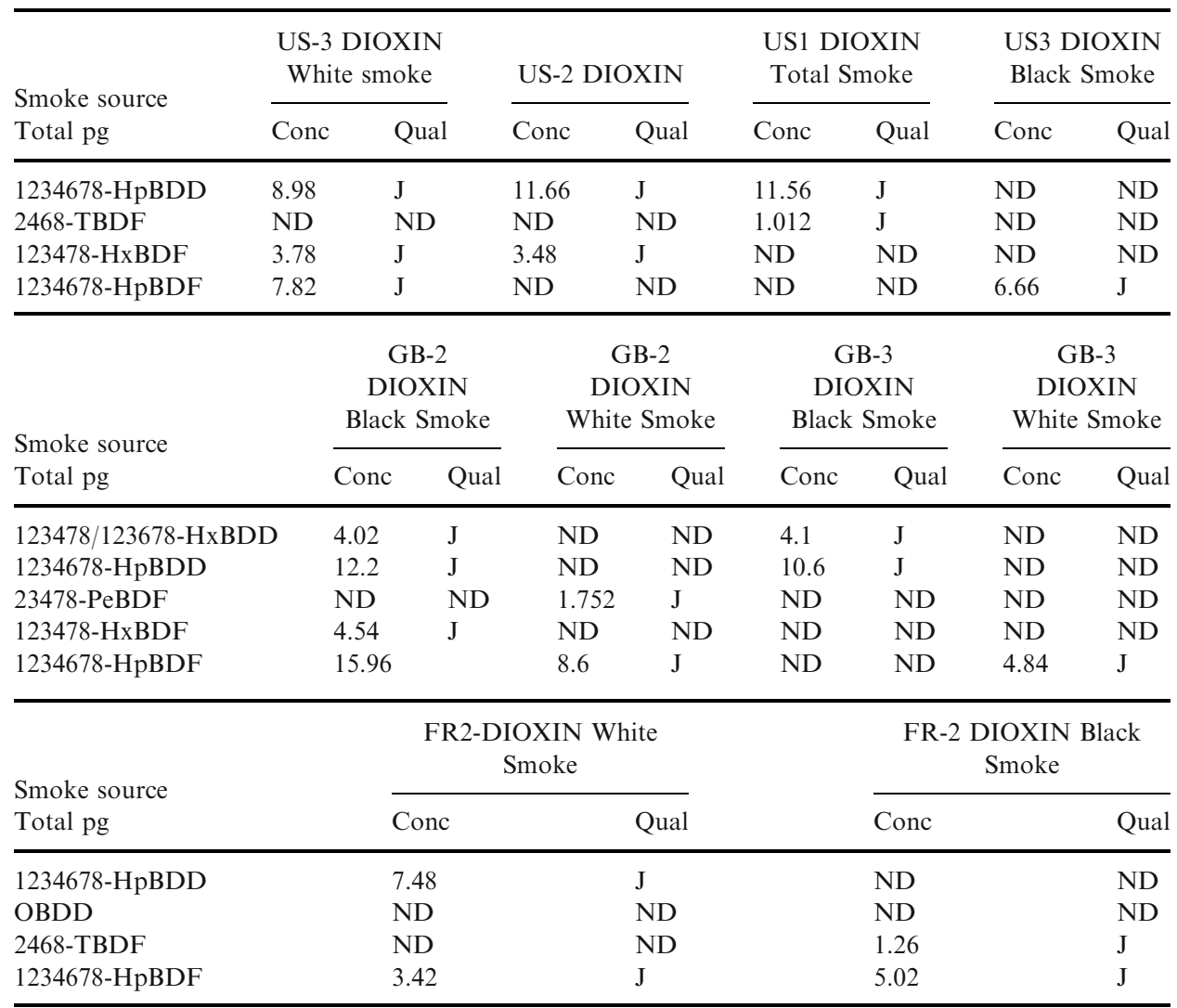

acutely toxic than the US and French configurations for at least 20 min into the burn, Table 3. This also was true for PAHs and chlorinated dioxins and furans for chronic toxicity, Tables 5 and 6 . The British configuration rooms also produced approximately half of total smoke, Table 3, compared to the French and US configuration rooms. However, the chronic toxicity of the smoke is outside of the scope of this paper.

Comparison of the heat release data showed that the British configuration is significantly less flammable than either the French or US configurations, which appear to be nearly identical in performance, Figures 4, 5 and 6, and Table 2. The work of Steinhage and Mierlo at Efectis supports this conclusion reporting the high heat release of individual sofas from United Kingdom is delayed by 15 to 20 min [19]. The British configuration produced less energy, had a lower pHRR, 
and delayed the pHRR by a factor of 5 . This affords as much as 5 times the escape time for a fire in this configuration as well as time for the fire department/ brigade to respond. Based on fire department response standards in the US [20], it is likely that a fire with this much delay could be extinguished before the structure is lost as well as allowing additional time for occupants to evacuate.

France and the United States currently require smolder only fire test standards for home furniture. The United Kingdom requires testing to a series of ignition sources, both smoldering and open flame. This study illustrated that the UK standard does provide a significantly better performance for an identical size and shaped couch based on pHHR, time to pHHR, time to peak smoke, and total smoke. In addition, the chemical composition of the smoke generated in the room burns featuring UK furniture were less acutely toxic based on $\mathrm{HCN}$ and $\mathrm{CO}$ emission and the chronic toxicity appears to be less based on the lower molecular weight and lower concentration of PAH produced. These results directly contradict results published by McKenna et al. [9]. The condition of the test do affect the results. It is critical to test under realistic conditions to be able to predict the performance of materials in home fires. Future research needs to focus on more realistic room designs that mimic ventilation conditions seen in real homes. Rooms with less ventilation as seen in a closed door room and better ventilation as seen in rooms with windows that may shatter represent possible examples.

The results obtained in this study are dependent on the room size and ignition sources selected. The amount of fuel in these studies while fairly realistic result in much lower oxygen levels and greater pHRR. UL performed a study where only a chair was tested in a similar sized room using a smaller ignition source and obtaining much lower pHRR and smoke as well as very different toxicity results [21].

\section{Acknowledgements}

This work was Funded by the North American Fire Retardant Association and the American Chemistry Council.

\section{Open Access}

This article is distributed under the terms of the Creative Commons Attribution 4.0 International License (http://creativecommons.org/licenses/by/4.0/), which permits unrestricted use, distribution, and reproduction in any medium, provided you give appropriate credit to the original author(s) and the source, provide a link to the Creative Commons license, and indicate if changes were made.

\section{ELECTRONIC SUPPLEMENTARY MATERIAL}

The online version of this article (https://doi.org/10.1007/s10694-019-00888-8) contains supplementary material, which is available to authorized users. 


\section{References}

1. Blais M, Carpenter K (2015) Combustion characteristics of flat panel televisions with and without fire retardants in the casing. Fire Technol 51(1):19-40

2. Blais M, Carpenter K (2015) Flexible polyurethane foams: a comparative measurement of toxic vapors and other toxic emissions in controlled combustion environments of foams with and without fire retardants. Fire Technol 51(1):3-18

3. Evarts B (2018) Fire loss in the United States during 2017, NFPA. https://www.nfpa.or $\mathrm{g} /$-/media/Files/News-and-Research/Fire-statistics-and-reports/US-Fire-Problem/osFireL oss.pdf. Accessed 6 June 2019

4. Patisaul $\mathrm{H}$ et al (2013) Accumulation and endocrine disrupting effects of the flame retardant mixture of firemaster 550 in rats: an exploratory assessment. J Biochem Mol Toxicol 27(2):124-136

5. BS 5852-2006 (2006) Methods of test for assessment of the ignitability of upholstered seating by smoldering and flaming ignition sources, 6th edn

6. FR EN 1021-1 (2014) Furniture. Assessment of the ignitability of upholstered furniture. Ignition source smoldering cigarette

7. Requirements, Test Procedures and Appratus for testing the smolder resistance of materials used in upholstered furniture, Technical Bulletin 117-2013, State of California Consumer Affairs. https://www.gsa.gov/cdnstatic/TB_117_2013

8. Standard Practices for Ignition Source, ASTM E3020-16a, 2016. https://compass.astm.o rg/EDIT/html_annot.cgi?E3020 + 16a

9. McKenna S et al (2017) Flame retardants in UK furniture increase smoke toxicity more than they reduce fire growth rate. Chemosphere. https://doi.org/10.1016/j.chemosphere. 2017.12.017

10. de Boer J, Stapleton H (2019) Toward fire safety without chemical risk. Science 364(6437):231-232

11. Stec AA, Hull TR (2011) Assessment of the fire toxicity of building insulation materials. Energy Build 43(2-3):498-506

12. Herschler M (2018) Rebuttal to "Flame retardants in UK furniture increase smoke toxicity more than they reduce fire growth rate". Chemosphere. https://doi.org/10.1016/j.ch emosphere.2018.07.123

13. Blais M (2018) Letter to the editor for chemosphere reference: flame-retardants in UK furniture increase smoke toxicity more than they reduce fire growth rate. Chemosphere. https://doi.org/10.1016/j.chemosphere.2018.07.176

14. ISO 9705-1: 2016 (E) Reaction to fire tests-room corner test for wall and ceiling lining products part 1: test method for a small room configuration

15. Guillaume E et al (2014) Real-scale fire tests of one bedroom apartments with regard to tenability assessment. Fire Saf J 70:81-97. https://doi.org/10.1016/j.firesaf.2014.08.014

16. NFPA Handbook, 19th edn, vol II, pp 8-24

17. Pocket Guide to Chemical Hazards, DHHS (NIOSH) Publication No 2005-149, Sept 2007

18. Blomqvist P et al (2012) Polycyclic aromatic hydrocarbons (PAHs) quantified in large scale fire experiments. Fire Technol 48:513-528

19. Steinhage, R. van Mierlo (2010) Reaction to fire testing of sofas, 210-Efectis-R1058

20. NFPA 1710, Standard for the Organization and Deployment of Fire Suppression Operations, Emergency Medical Operations, and Special Operations to the Public by Career Fire Departments, 2010 edn 
21. Black et al (2019) A study of chemical exposure risk and flammability of upholstered furniture and consumer electronics, Underwriters Laboratory report 050/2

Publisher's Note Springer Nature remains neutral with regard to jurisdictional claims in published maps and institutional affiliations. 